\title{
Do stocks outperform treasury bills?
}

\author{
Navya Ninan ${ }^{1}$ \\ ${ }^{1}$ Assistant Professor \\ Marian International Institute of Management, Kuttikkanam, Kerala - 685531, India
}

\begin{abstract}
"Stocks provide greater return potential than bonds, but with greater volatility along the way." You have probably heard that statement so many times that you simply accept it as a given. But have you ever stopped to ask why? Why have stocks historically produced higher returns than bonds? Why are bonds typically less volatile? This paper helps in understanding the reasons behind these trends. The study highlight the important role of positive skewness in the distribution of individual stock returns, attributable both to skewness in monthly returns and to the effects of compounding. The results help to explain why poorly-diversified active strategies most often underperform market averages.

Keywords: Risk and returns, Treasury bills, Stocks, return skewness, interest rates
\end{abstract}

\section{Introduction}

The policy-makers, economists and investors have equal interest in drawing an empirical relationship on the returns of stock and government securities. The mechanisms involved in linking these markets are understood by the economists. This helps financial market regulators to improve aggregation of market information and reduce the impact of shocks to the financial system. Whereas, the investors are concerned about the return through diversification of the portfolio.

Both treasury bills and stocks help investors to earn a return to meet the financial requirements. By investing in stock, the investor is having a stake in the company. With the rise and fall of stock market, the stock price tends to vary. Therefore, the initial investment is subject to market fluctuations. Whereas, through investment in treasury bill, the investor is making a loan to the government. Investment in government securities signifies the confidence of the investor in the government. It also helps to diagnose the health of the economy. Treasury bills come in different maturities ranging from 14 days to 364 days. The invested company going to bankruptcy is always a risk to investing in stocks. But, repayment in case of t-bill is certain. Thus, zero risk and smaller denominations are the major advantages of t-bills.

\section{Risk of Stocks}

Stocks are inherently risky and come with no guarantees. If you purchase a share of stock in a company and the company goes bankrupt or suffers from a major loss, you could easily lose 100 percent of your investment. Anything from a scandal to bad decisions by company leaders or even a weather emergency can significantly impact a company's stock price. Even if the price remains stable, you may never earn a premium or return on your investment.

\section{Risk of Treasury Bills}

Treasury bills are backed by the U.S. government. That means that the risk of nonpayment is virtually nonexistent. As long as the U.S. government remains in place, you will receive both your initial investment and a return on your investment if you hold the bill to term. In fact, "USA Today" calls Treasury bills the safest form of government loan because of their relatively short term. Compared to notes or bonds, which represent long-term loans, treasury bills pose virtually no risk to investors.

\section{Risk vs. Return}

Due to the higher risk associated with stocks, they traditionally provide a much higher return than Treasury bills. For example, stocks returned an average of 11.2 percent annually from 1928 to 2011, while Treasury bills returned just 3.66 percent, according to New York University's Stern Business School. This illustrates a lesser known risk of buying Treasury bills--the potential opportunity cost in terms of smaller returns compared to investing in stocks.

\section{Discussion}

(EPW Research, 2018) quotes that by the abandonment of primary lending for fruitful reasons; activities in the government securities market have enormously dominated both secondary and primary market. (Goyenko, Subrahmanyam, \& Ukhov, 2018) 
further add that there was an increase in illiquidity across bonds of all maturities during times of recession. However, the short term bonds experience a wider increase. The recession also witnessed a distinction in the spreads of short term and long term bonds. In the treasury market, off-the-run illiquidity contributes to the return forecastability.

The inter-linkage in the stock-bond is shaped by the agents' collective investment behavior. They use their competitive advantage to forecast the price movement in the other markets. During times of high market fluctuations, the technical traders drive the market by actively buying bonds and selling stocks (Li, Zheng, \& Leung, 2016). The impact of crises fluctuates over time frequencies while the fundamental economic factors that pilot the stockbond relations remain the same. And understanding this dynamics is important for policy making and in asset allocation (Lin, Yang, Marsh, \& Chen, 2017).

To explain the equity and bond risk, the macro finance factors identified are the term structure (term spread, t-bill rate, long-term yield and return etc.), credit risk (default yield and return spread), liquidity, the stock market (dividend yield, dividend price ratio, earnings price ratio, stock variance etc.), and other macro variables such as inflation, industrial production etc. (Aslanidis \& Christiansen, 2014). According to the concept of spatial dominance, (Ibarra, 2013) reveals that during the short investment horizons, bonds dominate stocks while in the long horizons stock tend to dominate the bond.

Investors are provided with wider diversification opportunities when emerging stock markets open up (Panchenko \& Wu, 2009). The bond and short term interest yields in the Euro area highly influenced by the shocks to the equity market of US. Similarly, the US bond market is significantly impacted by the variation in the short term interest rates in the Euro zone (Ehrmann, Fratzscher, \& Rigobon, 2018). The Indian stock and bond market are correlated unconditionally by a long-run relationship. The diversification benefits are ample when the bonds and stocks are combined in a portfolio. Still, India's government bond markets have a much lesser market capitalization than the equity market (Patoda \& Jain, 2012). Similarly, (Verner \& Herbrik, 2017) conclude that the government bond yields and the stock returns in Germany and US share a positive relationship until the European debt crisis.

The cash flow growth, risk aversion, output gap, risk premium, interest rates and inflation are the major determinants in the co-movement of stock and bond return (Baele, Bekkaert, \& Inghelbrecht, 2018). The expected return and risk are the major determinants of any investment avenue. The optimal portfolio allocation and the risk return trade-off is affected by the correlation between these two variables. The annual geometric means for the period $1871-2000$ were $4.34 \%$ and $9.08 \%$ respectively for the total bond and nominal stock returns (Jones et al., 2018). Further, (Siegel, 2018) says that the bonds are riskier than stocks in the long run. Stocks have proved to be excellent in long-term hedging against inflation. Economic theory suggests that the yield on TIPS (Treasury Inflation Protected Securities) should be consistent with the real GDP growth.

The supply of long term bonds is affected by the changes caused by the government. The shifts in the clientele demand and supply of bonds should be understood along with the changes in the inflation rates, short term interest rates and other macro economic factors (B. R. Greenwood \& Vayanos, 2010). The decisions made by the rational investors are highly influenced by the informational effectiveness of the bond and stock markets. The study further concludes that the daily bond returns are led by the daily stock returns. This indicates that the bond holders might have ample time to position their investments better (Tolikas, 2017).

Further, (Kolluri, Wahab, \& Wahab, 2015) adds that the Indian stock market is strongly influenced by the U.S. equity market. Being consistent with the growing capital markets, India's stock and bond returns propose an inverse relationship. Bond is a good hedge against stock market volatility, offering more diversified opportunities. For the negative coskewness between stocks and bonds, long term investors are willing to hold stocks demanding a higher return whereas they demand a lower return to hold bonds that have a positive co-skewness (Yang, Zhou, \& Wang, 2018). The barriers to arbitrage are reduced substantially by the depth and liquidity of US treasury market (Nielsen \& Pungaliya, 2017).

(Downing et al., 2018) suggests that the stock market is more efficient than the corporate bond market in terms of the market knowledge. Since bonds have relatively stable cash flows, there is a minimal correlation between highly rated bonds and stock returns. The return on safe bonds is relatively sensitive to the interest rate movements. The results also indicate that A-, AA- and AAA-rated bonds are strongly dependent on the returns of the Treasury notes. Similarly, the predictable convertible bonds have a higher mean bond and stock returns than for unpredictable convertible bonds. Due to the modifications in the interest rate risk, the expected returns and bond yield are predicted to rise with an increase in supply when the short rate is held constant. During times when arbitrageurs are resistant to take risk and for bonds with longer maturity, these effects would be stronger (R. Greenwood \& Vayanos, 2018).

With the increased involvement of the government in financial markets, the risks in treasury securities have also gone up. Taxation, maturity and liquidity should be taken into account along with the interest rates to compute the default risk (Nippani \& Smith, 2010). The treasury market is an indicator to 
benchmark riskless rates in the economy (Goyenko et al., 2018). When the safety and liquidity of government bonds are valued high by the investors, they expect a low return for holding them over the other investment alternatives (Du, Im, \& Schreger, 2018). By omitting those stocks that generate relatively large positive returns, a less diversified portfolio tends to underperform. The study concludes that most of the individual stocks underperform the T-bill with the least maturity (Shen \& Starr, 1998). Highly liquid treasury bonds are preferred over the less liquid stocks by investors during times of crisis (Baele et al., 2018).

Both on-the-run market (contracts issued recently) and off-the-run market (contracts issued previously) offer trading in treasury securities for a fixed maturity period. The uncertainty is reduced to an extent in case of securities traded in the off-the-run market. Before the equilibrium price is determined for a newly issued t-bill, the secondary market demand must be carefully analysed (Griffiths, Lindley, \& Winters, 2010). The differences in the maturity of bond and bills affect the net return, since both are not subject to default. The returns are primarily known as the 'liquidity premia'. The promised returns are measured by yield rather than the realized returns (Ibbotson \& Sinquefield, 2010).

Central bank bills and treasury bills are issued by some countries for open market operations. Emerging countries tend to employ more central bank bills whereas, advanced countries use treasury bills. The use of treasury bill reduces the fluctuations in the short-term interest rates and also the daily liquidity management is made easy (Yi, 2014). The studies also reveal that when the investors least value the returns realized on treasury bonds are high and low when they most value (Michelfelder \& Pilotte, 2011). Regardless of the investment horizon, maturity, issuer, risk involved, holding long position in treasury bills prove to have a good inflation hedging capacity. However, for investment durations of more than 6 months, the return of t-bills is positively correlated to the rate of inflation (Spierdijk \& Umar, 2015).

(Bessembinder, 2018) establishes a link between the bid-ask spread and the interest rates. The bid-ask spread is identified as important variable for premium computation. The standard deviation from the surplus holding period yield is quantified as risk. The price of the services is reflected by the market makers' exposure to risk. Still it is difficult to obtain bonds with wider bid-ask spreads and higher volatilities (Song \& Zhu, 2018)

\section{Conclusions}

The study implies that the returns to active stock selection can be very large if the investor is either fortunate or skilled enough to select a concentrated portfolio containing stocks that go on to earn extreme positive returns. Of course, the key question of whether an investor can reliably identify in advance such "home run" stocks, or can identify a manager with the skill to do so, remains.

\section{Reference}

[1] Aslanidis, N., \& Christiansen, C. (2014). Quantiles of the realized stock - bond correlation and links to the macroeconomy ir. Journal of Empirical Finance. https://doi.org/10.1016/j.jempfin.2014.03.007

[2] Baele, L., Bekkaert, G., \& Inghelbrecht, K. (2018). The Society for Financial Studies The Determinants of Stock and Bond Return Comovements. The Review of Financial Studies, 23(6), 2374-2428.

[3] Bessembinder, H. (2018). Do stocks outperform Treasury bills? Journal of Financial Economics, $1-18$. https://doi.org/10.1016/j.jfineco.2018.06.004

[4] Downing, C., Underwood, S., Xing, Y., Downing, C., Underwood, S., \& Xing, Y. (2018). The Relative Informational Efficiency of Stocks and Bonds: An Intraday Analysis. The Journal of Financial and Quantitative Analysis, 44(5), 1081-1102.

[5] Du, W., Im, J., \& Schreger, J. (2018). The U . S . Treasury Premium. Journal of International Economics, 112, 167-181. https://doi.org/10.1016/j.jinteco.2018.01.001

[6] EHRMANN, M., FRATZSCHER, M., \& RIGOBON, R. (2018). STOCKS , BONDS , MONEY MARKETS AND EXCHANGE RATES : MEASURING INTERNATIONAL FINANCIAL TRANSMISSION. Journal of Applied Econometrics, 26(6), 948-974. https://doi.org/10.1002/jae.1

[7] EPW Research, F. (2018). Government Securities Dominate Market. Economic and Political Weekly, 35(11), 869-875.

[8] Goyenko, R., Subrahmanyam, A., \& Ukhov, A. (2018). The Term Structure of Bond Market Liquidity and Its Implications for Expected Bond Returns. The Journal of Financial and Quantitative Analysis, 46(1), 111-139. https://doi.org/10.1017/S0022109010000700

[9] Greenwood, B. R., \& Vayanos, D. (2010). Price Pressure in the Government Bond Market. The American Economic Review, 100(2), 585-590.

[10] Greenwood, R., \& Vayanos, D. (2018). Bond Supply and Excess Bond Returns. The Review of Financial Studies, 27(3), 663-713. https://doi.org/10.1093/rfs/hht133

[11] Griffiths, M. D., Lindley, J. T., \& Winters, D. B. (2010). Market-making costs in Treasury bills : A benchmark for the cost of liquidity. Journal of Banking and Finance, 34(9), 2146-2157. https://doi.org/10.1016/j.jbankfin.2010.02.004

[12] Ibarra, R. (2013). A spatial dominance approach to evaluate the performance of stocks and bonds: Does the investment horizon matter? Quarterly 
Review of Economics and Finance, 1-11. https://doi.org/10.1016/j.qref.2013.03.001

[13] Ibbotson, R. G., \& Sinquefield, R. A. (2010). Stocks, Bonds, Bills, and Inflation: Year-byYear Historical Returns ( 1926-1974 ). The Journal of Business, 49(1), 11-47.

[14] Jones, C. P., Wilson, J. W., Financial, S., Journal, A., Feb, N. J., Jones, C. P., \& Wilson, J. W. (2018). The Changing Nature of Stock and Bond Volatility The Changing Nature of Stock and Bond Volatility. Financial Analysts Journal, 60(1), 100-113.

[15] Kolluri, B., Wahab, S., \& Wahab, M. (2015). An examination of co-movements of India's stock and government bond markets §. Journal of Asian Economics, 41, 39-56. https://doi.org/10.1016/j.asieco.2015.10.001

[16] Li, M., Zheng, H., \& Leung, T. T. (2016). Author's Accepted Manuscript trading The Stock-Bond Comovements and Cross-Market Trading. Journal of Economic Dynamics and Control. https://doi.org/10.1016/j.jedc.2016.10.007

[17] Lin, F.-L., Yang, S.-Y., Marsh, T., \& Chen, Y.F. (2017). Stock and bond return relations and stock market uncertainty: Evidence from wavelet analysis. International Review of Economics and Finance. https://doi.org/10.1016/j.iref.2017.07.013

[18] Michelfelder, R. A., \& Pilotte, E. A. (2011). Journal of Economics and Business Treasury Bond risk and return, the implications for the hedging of consumption and lessons for asset pricing. Journal of Economics and Business, 63(6), 582-604. https://doi.org/10.1016/j.jeconbus.2011.06.001

[19] Nielsen, Y., \& Pungaliya, R. S. (2017). Idiosyncratic returns and relative value in the US Treasury market. Journal of Empirical Finance, 44(October), $125-144$. https://doi.org/10.1016/j.jempfin.2017.09.003

[20] Nippani, S., \& Smith, S. D. (2010). The increasing default risk of US Treasury securities due to the financial crisis. Journal of Banking and Finance, 34(10), 2472-2480. https://doi.org/10.1016/j.jbankfin.2010.04.005
[21] Panchenko, V., \& Wu, E. (2009). Time-varying market integration and stock and bond return concordance in emerging markets q. Journal of Banking and Finance, 33(6), 1014-1021. https://doi.org/10.1016/j.jbankfin.2008.10.016

[22] Patoda, R., \& Jain, K. (2012). Assimilation between Bond Market and Stock Market. Global Journal of Management and Business Research, 12(20).

[23] Shen, P., \& Starr, R. M. (1998). Liquidity of the Treasury Bill Market and the Term Structure of Interest Rates. Journal of Economics and Business, 6195(98), 401-417.

[24] Siegel, J. J. (2018). Earnings , Inflation , and Future Stock and Bond Returns. Proceedings of the American Philosophical Society, 158(3), 222-228.

[25] Song, Z., \& Zhu, H. (2018). Quantitative easing auctions of Treasury bonds. Journal of Financial Economics, 128(1), 103-124. https://doi.org/10.1016/j.jfineco.2018.02.004

[26] Spierdijk, L., \& Umar, Z. (2015). Journal of Economics and Business Stocks, bonds, T-bills and inflation hedging: From great moderation to great recession. Journal of Economics and Business, 79, 1-37. https://doi.org/10.1016/j.jeconbus.2014.12.002

[27] Tolikas, K. (2017). The lead-lag relation between the stock and the bond markets. The European Journal of Finance, 0(0), 1-21. https://doi.org/10.1080/1351847X.2017.1340320

[28] Verner, R., \& Herbrik, G. (2017). Bond yields and stock returns comparison using wavelet semblance analysis. Investment Management and Financial Innovations, 14(2), 281-289. https://doi.org/10.21511/imfi.14(2-1).2017.12

[29] Yang, J., Zhou, Y., Wang, Z., \& Wang, Z. (2018). Conditional Coskewness in Stock and Bond Markets : Time-Series Evidence. Management Science, 56(11), 2031-2049.

[30] Yi, J. (2014). Treasury Bills and Central Bank Bills for Monetary Policy. Procedia - Social and Behavioral Sciences, 109, 1256-1260. https://doi.org/10.1016/j.sbspro.2013.12.62 